\title{
Effects of New Financial Reporting Standards on Value Relevance-A Study about Turkish Stock Markets
}

\author{
F. Ayzer Bilgic ${ }^{1,2} \&$ Cemal İbis ${ }^{1}$ \\ ${ }^{1}$ Institute of Social Sciences, School of Business Administration, Marmara University, Istanbul, Turkey \\ ${ }^{2}$ Borsa Istanbul A.S., Istanbul, Turkey \\ Correspondence: F. Ayzer Bilgic, Borsa Istanbul A.S., 34467 Emirgan, Istanbul, Turkey. Tel: 90-212-298-2567. \\ E-mail: ayzer.bilgic@borsaistanbul.com.
}

Received: June 17, 2013

doi:10.5539/ijef.v5n10p126

\author{
Accepted: August 26, 2013 Online Published: September 26, 2013 \\ URL: http://dx.doi.org/10.5539/ijef.v5n10p126
}

\begin{abstract}
Financial statement information that make the users to evaluate their decisions is value relevant. This paper aims to determine the value relevance of financial statement information in Turkish stock markets during the period of 1997-2011 by Ohlson Model (1995) and separate regressions. Starting from 2003, new regulations about financial reporting standards became effective. Consolidation and inflation accounting were put into action in 2003 annual financial statements. Afterwards in 2005, the revised translation of International Financial Reporting Standards (IFRS) was applied. And finally in 2008, one by one translation of IFRS named as Turkish Financial Reporting Standards (TFRS) became effective. So, we also aim to test whether the acceptance of new financial reporting standards made improvements on value relevance of accounting information or not in Turkish stock markets. Our results reveal that earnings and book values both together and separately are significantly value relevant. The explanatory power of book values are higher than the explanatory power of earnings. After new reporting standards, there is an increase in the value relevance of earnings and book values together and this increase is mainly due to the increase in the value relevance of book values.
\end{abstract}

Keywords: value relevance, Ohlson Model, IFRS, disclosure, Turkish stock markets, Borsa Istanbul A.S., IMKB

\section{Introduction}

This paper analyzes the value relevance of financial statement information on Turkish stock markets during the 1997-2011 period and also determines whether the new financial reporting standards starting from 2003 annual financial statements by Capital Markets Board of Turkey (CMB) led to any improvement on value relevance of accounting information in Turkish stock markets.

The accounting systems' main purpose is to provide the investors with relevant information that is useful for investment decisions. In that respect, financial statement information that makes its users to evaluate their decisions is value relevant. In other words, a financial statement item which has a relation with stock prices is value relevant.

Starting from 2003, CMB put into force new regulations about financial reporting standards. Firstly, consolidation and inflation accounting became effective starting from 2003 annual financial statements. Afterwards in 2005, for harmonization with European Union regulations the revised translation of International Financial Reporting Standards (IFRS) came into force. And finally in 2008, complete translation of IFRS named as Turkish Financial Reporting Standards (TFRS) became effective.

The aim of this paper is to analyze the value relevance of financial statement disclosures on Turkish stock markets during the 1997-2011 period and also to determine whether new regulations by CMB improved the value relevance of financial statements in Turkish stock markets.

Our results reveal that, financial statement information is significantly value relevant in Turkish stock markets during the period of 1997-2011. After the introduction new reporting standards, there is an increase in the value relevance of earnings and book values together. While new standards increase the value relevance of book values, we see a decrease in the value relevance of earnings. 


\section{The Rationale of New Financial Reporting Standards}

The Turkish Uniform Accounting System was published by the government in 1992 and starting from 1994, Turkish companies prepared financial statements in accordance with these generally accepted accounting principles. On the other hand, Istanbul Stock Exchange (IMKB) companies have to prepare their financial statements in accordance with CMB's Communiqué Serial: XI, No:1 "The Communiqué About the Principals and Rules about Financial Statement and Reports in Capital Markets" (Note 1). These double standards created two different financial statements for IMKB companies: one prepared for tax purposes and the other for capital markets purposes.

During the period between 1994 and 2009, Turkey faced important economic and financial crisis. In the first quarter of 1994, as a result of the uncontrolled growth in domestic debt stock, Turkish Lira depreciated by almost $70 \%$ against the US Dollar. The Central Bank's intervention in the foreign exchange market led to the loss of more than half of its international reserves. The currency crisis was followed by a banking crisis and overnight interest rates jumped from around 70\% to nearly $700 \%$ and economic growth declined by $6 \%$ (Ozatay, 1994). 1994 crisis was followed by a stabilization program supported by an International Monetary Fund (IMF) stand-by agreement in 1994 (Uygur, 2010).

The Asian and particularly Russian crises caused the 1998 and 1999 crises in Turkey. Negative growth and inflation rates over $60 \%$ followed by a "disinflation programme" accompanied by the 17 th stand-by agreement with IMF by end of 1999 (Uygur, 2010).

The pre-crisis conditions of 2000 were characterized by macroeconomic instability, high public sector deficit and systematic distortions created by the state and the weak banking sector. In November 2000, a liquidity crisis emerged as a sudden capital outflow. While interest and exchange rates were increasing, short term bank loans decreased. Turkish currency devaluated by $50 \%$, the negative balance of payments, current deficit and total debt stock amounted (Temiz \& Gokmen, 2009). Banks had huge foreign exchange losses. During the 1999-2003 period Savings Deposit and Insurance Fund took over the control and management of 19 banks, 5 of which were IMKB listed banks. This case affected not only the listed banks, but also the other listed companies that belonged to the same group with these banks. After this crisis, the 18th stand-by agreement with the IMF was put into force.

The global crisis in 2008 also affected Turkey by spreading to financial markets and trade. Similar to other emerging countries, net capital outflows, currency depreciation, a fall in stock prices (by around $60 \%$ from the peak of late 2007), rising risk premia and tightening liquidity in the banking sector appeared. Uncertainties caused sharp losses in business and consumer confidence. Sharp decreases in household consumptions and corporate investment followed (Rawdanowicz, 2010).

These crises also affected the relevancy and reliability of disclosed financial information and harmed investors' trust in stock markets and in turn had serious effects on IMKB too. Figures 1 and 2 demonstrate that total traded volumes decreased and total market values seriously deteriorated during crises periods seriously.

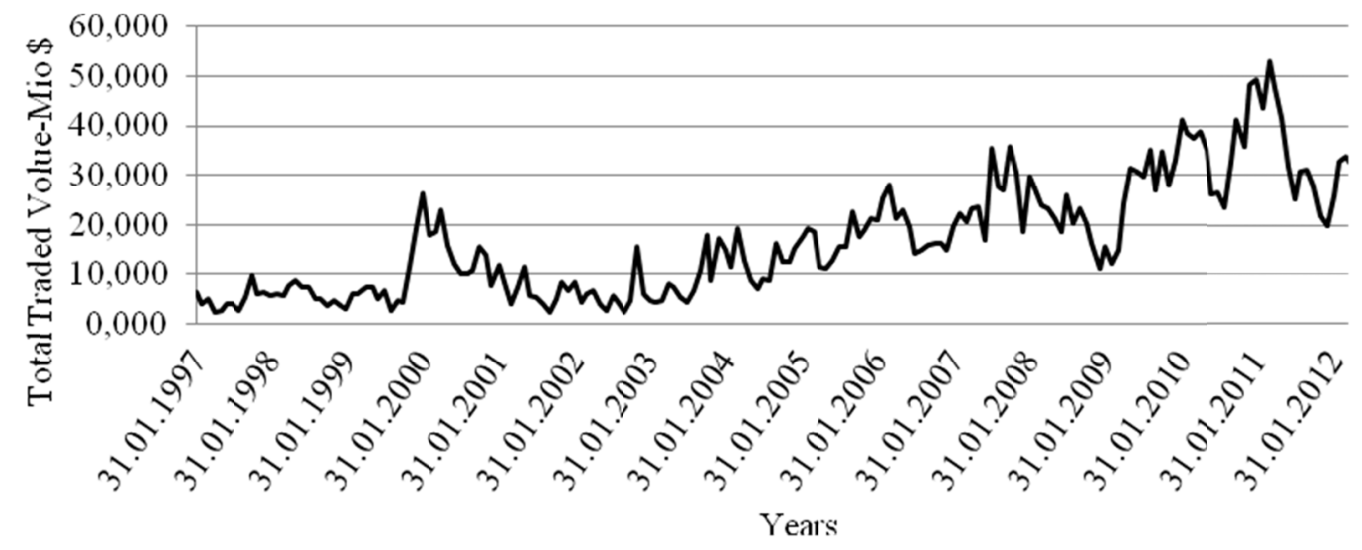

Figure 1. IMKB total traded volume figures between 1997-2012 


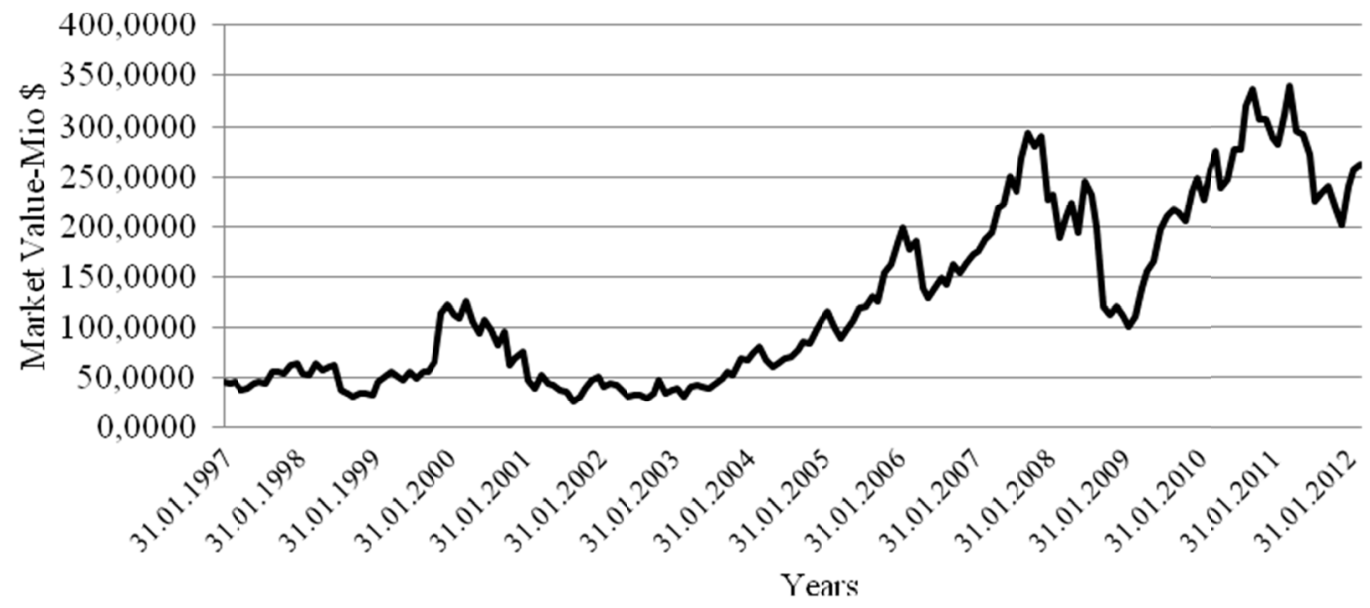

Figure 2. IMKB total market value figures between 1997-2012

There were important differences between IFRS and CMB's financial reporting standards:

1). The Communiqué Serial: XI, No:1 didn't regulate the consolidation. Although most of the Turkish companies are family/group companies with intense commercial or noncommercial relations with other group companies owned by the family or the same group, parent companies were not required to prepare consolidated financial statements. Therefore, it was impossible for both market and regulatory authorities to evaluate the risks associated with companies due to intense commercial or noncommercial relations among group companies since financial statements reflect only the figures for individual company. Notes to the financial statements about these group relations were not sufficient to draw a real picture of the company's financial situation operating under a group of companies, either. Therefore, especially the 2001 crisis showed that among other things, there were serious problems in transparency of listed companies, especially of group companies.

2). In spite of high inflation rates, Communiqué Serial: XI No:1 didn't regulate the hyperinflationary adjustments of financial statements. The annual changes in consumer price index rates for the 1995- 2012 period can be seen in the Table 1. Until 2003, the financial statements without inflation adjustments did not reflect the real financial situation of listed companies.

Table 1. Annual change in consumer price index (1995-2011)

\begin{tabular}{cc}
\hline Year & Change in Consumer Price Index As End of Year (\%) \\
\hline 1995 & 76.05 \\
1996 & 79.76 \\
1997 & 99.09 \\
1998 & 69.73 \\
1999 & 68.79 \\
2000 & 39.03 \\
2001 & 68.53 \\
2002 & 29.75 \\
2003 & 18.36 \\
2004 & 9.32 \\
2005 & 10.53 \\
2006 & 9.65 \\
2007 & 8.39 \\
2008 & 10.06 \\
2009 & 6.53 \\
2010 & 6.40 \\
2011 & 10.45 \\
\hline
\end{tabular}

Source: Turkish Statistical Institue, www.tuik.gov.tr.

3). Communiqué Serial: XI No:1 did not include the rules for the disclosure of (i) statement of changes in equity, (ii) fair values of financial assets and liabilities except for marketable securities (iii) discontinuing operations (iv) segment reporting and (v) related party transaction other than shareholders, subsidiaries and other equity 
participants (GAAP 2001).

4). There were differences between the related Communiqué and IFRS in terms of (i) impairment of assets, (ii) de-recognition of financial assets, (iii) hedge accounting (iv) employee benefits (v) Financial instruments' accounting (GAAP 2001).

5). There were other inconsistencies between two standards. We can summarize the differences in CMB regulations as follows: (i) Available-for-sale and derivative financial assets and liabilities are not recognized at fair value (ii) Capitalization of foreign exchange losses as part of costs of assets under some circumstances (iii) Non capitalization of finance leases (iv) Pension obligations are not discounted (v) Deferred tax liabilities are accounted for partially on the basis of timing differences (vi) Deferred tax assets are not allowed (vi) A broader definition of the extraordinary items (vii) Different classification for cash flow statement items (vii) Difference in the calculation of earnings per share, the denominator is not adjusted for bonus shares (viii) Capitalization of pre-operating, set-up and research costs (ix) Keeping inventories at above net realizable value in some circumstances $(\mathrm{x})$ Valuation of inventories at the lower of cost and replacement cost. (vii) Accounting for construction contracts on a completed contract basis (GAAP 2001).

In order to overcome all these shortcomings, starting from 2003, CMB put new regulations in force. First of all, consolidation and inflation accounting became effective starting from the annual financial statements of 2013. Afterwards in 2005, for harmonization with European Union regulations the revised translation of IFRSs came into force. And finally in 2008, Turkish translation of IFRS named as TFRS became effective.

\section{Previous Research}

According to Lev (1989), the main logic behind the accounting data and price relation rests on information (communication) theory. According to this theory, a message (like accounting information) that changes the receiver's probability distribution (beliefs) of the concerned random variable is accepted as conveying information. That change in the probability distribution initiates an action such as a change in the share price or volume. At the end, if this action can be attributed to specific information, then that information is considered useful.

Earnings or after tax net income is an indicator of a company's performance. It is a measure of the company's profit or loss from business operations during the related accounting period.

Nichols and Wahlen (2004) explain the relation between earnings and stock returns in three links (Figure 3).

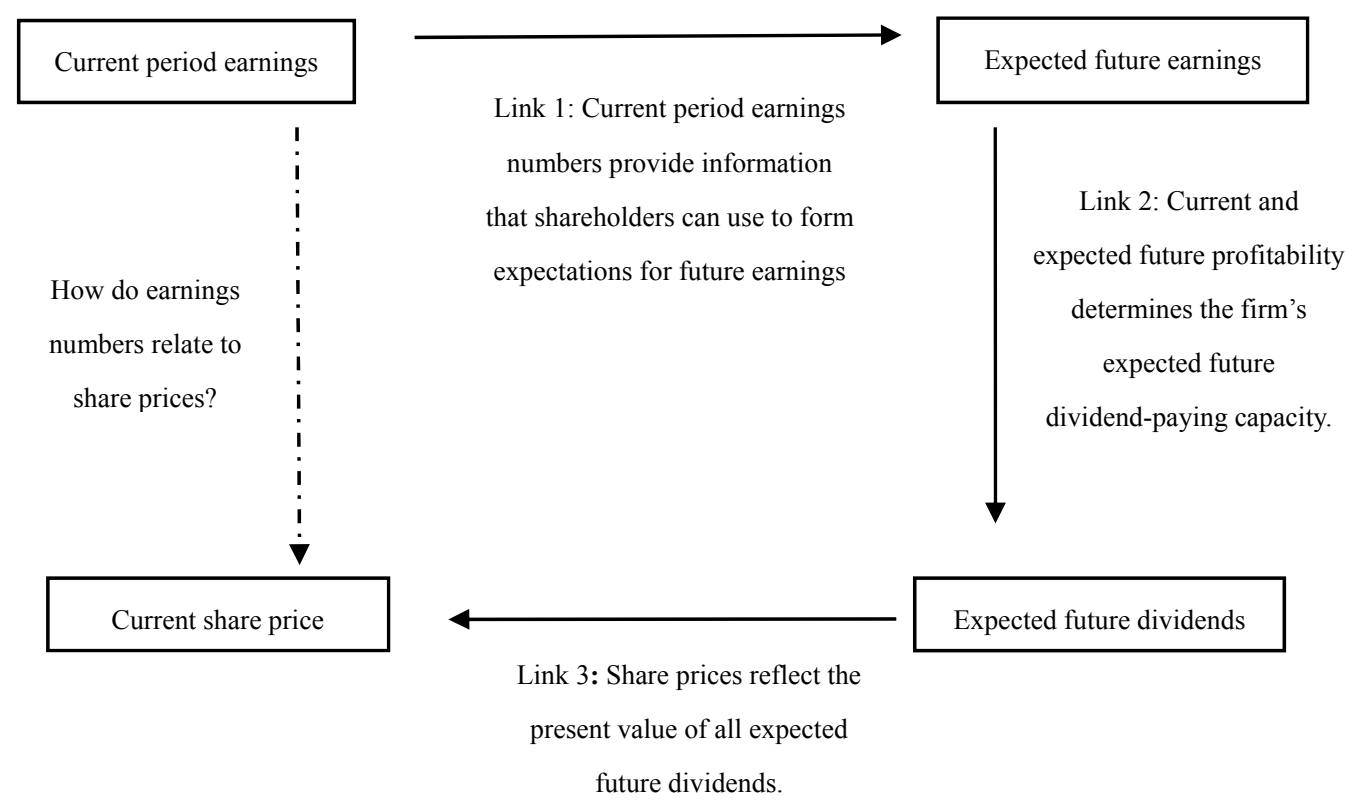

Figure 3. The relation between earnings numbers and share prices (Nichols \& Wahlen, 2004) 
Link 1- Earnings or financial reporting disclosure provides information to shareholders about both current and expected future profitability of company. Earnings measured by means of accrual accounting principles demonstrate the effects of transactions and events on shareholders' equity. So, current period net income summarizes important information about the wealth created by the firm for shareholders during the reporting period. Also, net income and financial statement information provide information to predict future earnings (Nichols \& Wahlen, 2004).

Link 2- Current and expected future earnings also gives information about the company's current and expected future dividends (Nichols \& Wahlen, 2004).

Link 3- Share price equals to the present value of the company's expected future dividends to the shareholder (Nichols \& Wahlen, 2004).

These three links together imply that new accounting data provide information that changes the investors' expectations for future dividends, which creates a change in the market value of the company (Nichols \& Wahlen, 2004). In other words, a financial statement item is relevant if it makes users of financial information to evaluate their decisions and expectations and it is reliable if it represents what it aims to represent. An accounting number that has an estimated relation with stock prices is accepted as value relevant (Barth, Beaver, Landsman, 2001).

According to Barth et al. (2001), value relevance research is a case in point, where the overall explanatory power and coefficients are estimated from regressions of returns or stock prices on earnings and other accounting measures are interpreted as evidence of the combined relevance or reliability of the financial reporting information.

In general, it is possible to classify the value relevance studies into two (Figure 4):

i) Those examining the association between earnings and return (usually measured over a twelve-month or longer period)-association based studies.

ii) Those drawing causal inferences from the event of earnings announcement - event studies or information content studies.

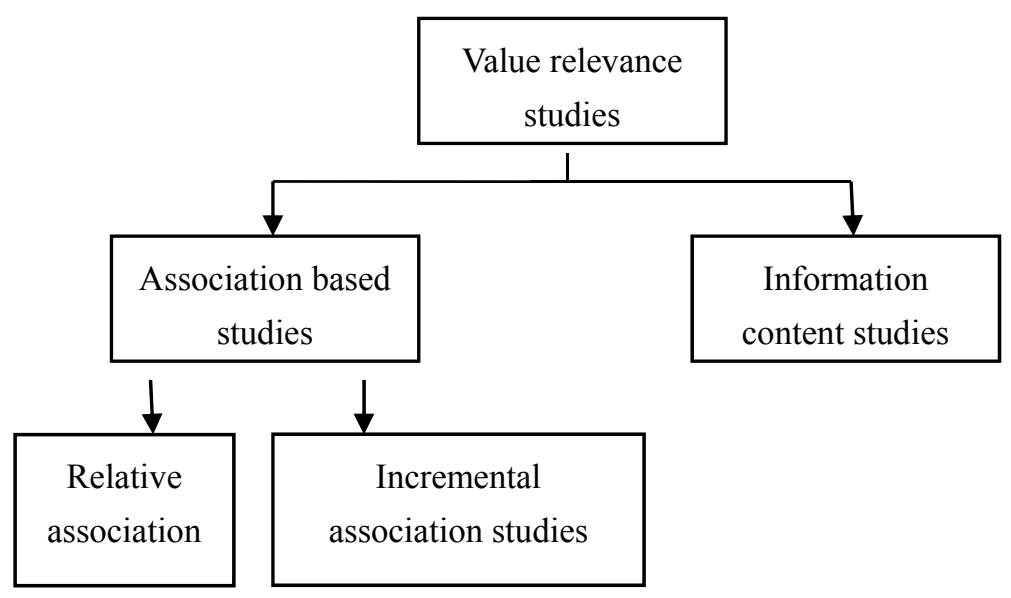

Figure 4. The classification of value relevance studies

\subsection{Association Based Studies}

According to Easton (1999), association based studies examine the effectiveness of accounting data as a summary of the events that have affected the company. These studies analyze the statistical relation between financial information and prices or returns. In other words these studies measure whether the new financial statement information revise investors' expectations (Francis \& Schipper, 1999).

Association based studies don't look for a relation between financial statement information and share price movements. In these tests the correlation between the accounting performance measures such as earnings and stock returns are assessed over relatively long periods. In addition to financial statements, there are other timely and important information available to investors about the companies. Hence, the objective of these studies is to test whether and how fast accounting measures capture changes in the information set that is reflected in security 
returns over a given period (Kothari, 2001).

Holthausen and Watts's (2001) group association studies into two:

i) Relative association studies: These studies compare the relation between share prices or changes in prices and different financial statement items. Differences in the $\mathrm{R}^{2}$ values are being tested by means of financial statement items and the accounting numbers with higher $\mathrm{R}^{2} \mathrm{~s}$ are defined as more relevant.

ii) Incremental association studies: These studies test whether the accounting numbers are helpful in explaining value or returns over the long windows are being tested. If the estimated regression coefficient of the accounting number is different from zero, then the related accounting number is accepted value relevant.

\subsection{Information Content Studies}

Information content studies mainly examine the reaction of the market to information announcement. In other words, these studies investigate whether a particular accounting number adds to the information set available to investors. These are mainly the event studies with short window return studies and are used to determine whether the release of financial statement item is associated with value or volume changes. Price reactions are evaluated as evidence of value relevance (Holthausen \& Watts's, 2001). The accounting event that conveys new information about the amount, timing and/or uncertainty of future cash flows and revise the market's related expectations, then variability in prices is expected around the announcement date. Event studies are based on the assumption that capital markets are informationally efficient. So, shares prices immediately reflect the new disclosed information (Kothari, 2001).

Value relevance of financial statement information is a very popular subject in accounting research and used in many different aspects. The studies on the change of value relevance of financial statement information over time are one of these aspects. These studies are mainly for regulatory purposes. According to Francis and Schipper (1999) the decrease or increase in the value relevance of financial statement information may be due to the accounting standards and practices that remained constant in spite of the changes in businesses and their requirements or due to the changes in accounting standards.

Ball and Brown (1968) show that earnings increases (decreases) are associated (on average) with positive (negative) abnormal returns over the 12 months prior to earnings' announcement and the unexpected component of earnings tends to have the same sign as unexpected price changes. Market reacts with an increased trading volume and price variability during the earnings announcement week due to the information content that the earnings possess (Beaver, 1968). Bamber's (1986) study on the information content of earnings shows the relationship between earnings releases and trading volume as Beaver (1968). She finds that the greater the absolute value of earnings surprise, the greater the volume of trading around the annoucement date. Also, the reaction of smaller firms is greater than that of larger firms (Bamber, 1986).

In a study by Landsman and Maydew (2002), the information content of quarterly earnings was analyzed with two information content measures, namely abnormal trading volume and abnormal stock volatility with over 90000 sample companies during the period 1972-1998. That study also found an increase in informativeness of accounting information rather than a decrease.

Ohlson's (1995) study demonstrates the relation between price, book value and earnings. His model is widely used in value relevance research in order to test the relevance of accounting information. The basic underlying assumption under the model is "clean surplus accounting" which requires all changes in assets and liabilities to be recognized in the income statement, except for dividends. The statement of changes in owners' equity includes the bottom line items in balance sheet and income statement and the change in book value should be equal to earnings less dividend (net of capital distributions). The other assumption of the model is the irrelevance of dividends, which means that although dividends decrease the book value, it does not have an effect on earnings. And the final assumption is that residual (abnormal) earnings follow a linear pattern.

Collins, Maydew and Weiss (1997) analyze earnings and book values' value-relevance over time using Ohlson Model. They decompose the combined explanatory power of earnings and book values into three components: i) the incremental explanatory power of book values ii) the incremental explanatory power of earnings iii) the explanatory power common to both earnings and book values. They find that, the combined value relevance of earnings and book values has not declined over the past 40 years. They also report that while the incremental value-relevance of "bottom line" earnings has declined, it has been replaced by increasing value relevance of book values.

Collins, Pincus and Xie (1999) examine the role of book value of equity in the price-earnings relation for loss companies and show that when book value of equity is included in the price-earnings relation, the coefficient of 
earnings for these companies is significantly different from zero in each year of their 18 -year sample period between 1974 and 1993. They conclude that the inclusion of book values to the earnings-price relation eliminates the anomalous negative coefficient on earnings. According to Collins et al (1999), the reason for this is the fact that the book value of an equity is a control for scale differences and book value is more important for loss companies.

Francis and Schipper (1999) find that the explanatory power of earnings has decreased significantly over time. On the other hand, explanatory power of assets and liabilities for prices don't provide any evidence of a decline in balance sheet relation.

Lev (1989) explains three reasons for the low explanatory power of earnings: i) Low explanatory powers can be due to the inefficiency of the market. If investors systematically false with financial information or if they overreact to or ignore relevant information, in other words if they trade in a noisy way, then the explanatory power of financial information is low. ii) Even though the financial information is important, the methodologies used by researchers may not be successful in proving that importance. iii) In fact there is a weak relation.

Brimble and Hodgson (2007), gives five reasons for declining value relevance: i) Business environment that is more volatile and service oriented. ii) Changes in risk origins and degrees, a general increase in security returns' volatility, iii) Historic cost accounting practices, v) Technological developments, v) Increased information requirements by investors. In their study, Brimble and Hodgson (2007) extend the USA research that finds the declining value relevance to Australian data. Their linear regressions support the USA findings with declining value relevance. But their nonlinear analysis with some additional adjustments for nonlinearities and stock market inefficiencies reveal that these adjustments significantly increase the explanatory power of the model. They also find that explanatory power of book values are not as high as the explanatory power of earnings. And finally they conclude that conventional accounting information has not become less value relevant, there is simply more complex financial environment.

Value relevance studies also are used to investigate the effects of new accounting standards for regulatory purposes. High quality accounting standards are required for investor confidence, which in turn improves liquidity and reduces cost of capital and contributes to the efficiency of capital markets.

Jermakowicz, Kinsey and Wulf (2007) examine the challenges and benefits of the IFRS adoption of DAX-30 companies. Their analysis is based on the annual data for the period of 1995-2004. They test the value relevance of the earnings and book values before and after acceptance of IFRSs or US GAAP or cross listing on NYSE by DAX-30 companies, using 265 observations. And they find that IFRS or US GAAP or cross listing significantly increase the value relevance.

Clarkson, Douglas, Richardson and Thompson (2009) investigate the impact of IFRS adoption in Europe and Australia in terms of the value relevance of book value and earnings. Using traditional linear pricing models, they find that earnings and book values measured under IFRSs have the same explanatory power with the ones measured with local GAAP. They repeat their analysis by dividing the companies as Common Law and Code Law originated, then they find a decrease in relevance for Common Law countries, but an unchanged relevance for Code Law countries.

Devalle, Onali and Magarini (2010) analyze the effects of mandatory IFRS adoption by European listed companies during the 2002-2007 period. They estimate panel data regressions using data for 3721 listed companies. Their findings are summarized in Table 2 .

Table 2. Effects of IFRS adoption in European Union

\begin{tabular}{lccc}
\hline \multicolumn{1}{c}{ Country } & $\begin{array}{c}\text { Combined Explanatory } \\
\text { Power }\end{array}$ & Value Relevance of Book Value & $\begin{array}{c}\text { Value Relevance of } \\
\text { Earnings }\end{array}$ \\
\hline Germany & Decreased & Decreased & Increased \\
Spain & Decreased & Decreased & Decreased \\
France & Increased & Decreased & Increased \\
Italy & Decreased & Decreased & Decreased \\
United Kingdom & Increased & Increased & Increased \\
Whole sample & Increased & Decreased & Increased \\
\hline
\end{tabular}

Armstrong, Barth and Riedl (2010) analyze the market reaction to IFRS adoption in Europe. They find incrementally positive reaction for European firms with lower pre-adoption information quality and higher pre-adoption information asymmetry and improved information quality. 
There are also studies about the effects of IFRS adoption in Turkish stock markets. Dincer (2009) studies on whether the mandatory IFRS adoption has a positive impact on information asymmetry in IMKB. She uses the weekly data from January 2003 to December 2007 and divides the sample period into two as before and after IFRS adoption, in other words before and after 2005. In order-driven markets adverse selection cost and order-processing cost constitute the main components of the bid-ask spread which is an indicator of how investors perceive information asymmetry problems on capital markets. She uses serial covariance model and finds the existence of the adverse selection cost in IMKB (about 37\%). Her results demonstrate that the difference in means of bid-ask spread, trading volume, share price volatility and market value (firm size) over time (pre-adoption and post-adoption period of IFRS) is statistically significant. Also, her results indicate significant reductions in bid-ask spread after IFRS adoption.

An early study by Turel (2009) analyses whether IFRS adoption increased value relevance in Turkey or not. In that respect, he compares the value relevance of financial statements of 198 listed Turkish companies during 2001-2005 period (before IFRSs) and of 208 companies between the period of 2005-2006. He uses Ohlson's (1995) prices, earnings and book value relation with the end of year share prices. He also tests the price - earnings and price- book value relations separately. He finds that i) earnings coefficients turned to positive and increased significantly from CMB accounting standards period to IFRS period ii) incremental value relevance of earnings increased after the introduction of new regulations, but value relevance of book values decreased.

The study by Suadiye (2012) analyses the value relevance of book values and earnings under the local GAAP and IFRS. She uses Ohlson's (1995) model for the period of 2000-2009. She also tests the earnings- prices and book values-prices relations separately. She uses per share stock prices six months after the fiscal year's end of time and annual financial information. She finds an adj- $\mathrm{R}^{2}$ of $16.70 \%$ for local standards for the period of $2000-2002$ and $33.23 \%$ for IFRSs in 2005-2009. Her results indicate that the value relevance of accounting information improved with the adoption of IFRSs.

Kargin (2013) tests the impact of IFRS on value relevance of accounting information in IMKB during the 1998-2011 period with Ohlson's (1995) model. Her sample size is not constant through the years. There are 136 and 155 sample companies, respectively in 1998 and in 2011. She compares the value relevance of the pre-IFRS period (1998-2005) with the post-IFRS period (2005-2011). She finds that book values and earnings jointly explain $38 \%$ of the cross sectional variation in stock prices for the whole sample period. She also repeats the test for sample firms with positive earnings and finds an adj- $\mathrm{R}^{2}$ of $47 \%$. In order to compare the results of the two periods, she also adds dummy variables for earnings and book values to the equation. Her analysis reveals that the overall book value is value relevant in determining stock prices, and that value relevance of accounting information has improved in post IFRS period considering book values while an improvement has not been observed in value relevance of earnings.

\section{Data and Methodology}

\subsection{Sample Selection and Data}

In order to make the results comparable throughout the years, we hold the sample firms constant during the analysis period. In that respect, the IMKB companies that survived between the period of 1997-2011 and that have the accounting period of 01.01-31.12 are included in the sample. Companies from regulated sectors like banking, insurance, leasing, factoring and companies whose shares' trading were suspended temporarily by IMKB during financial statement announcement dates, due to several reasons such as manipulation investigation are excluded. In consideration of these 119 companies are determined. Then, for each independent variable to be tested for the period of 1997-2011, the ones that are outside the range of $+/-3$ standard deviations of the mean are determined as outliers and these companies are excluded from the sample. At the end the sample consisted of 113 companies of which the industrial distribution is as in the Table 3. 
Table 3. Industrial distribution of sample companies

\begin{tabular}{lcc}
\hline Sectors & Number of Companies & $\%$ \\
\hline Non-Metallic Mineral Products & 20 & 17.70 \\
Chemicals, Petroleum, Rubber and Plastic Products & 15 & 13.27 \\
Fabricated Metal Products, Machinery and Equipment & 15 & 13.27 \\
Food, Beverage and Tobacco & 12 & 10.62 \\
Textile, Wearing Apparel and Leather & 12 & 10.62 \\
Basic Metal Industries & 10 & 8.85 \\
Paper and Paper Products, Printing and Publishing & 7 & 6.19 \\
Holding and Investment Companies & 7 & 6.19 \\
Wholesale and Retail Trade, Hotels and Restaurants & 6 & 5.31 \\
Technology & 3 & 2.65 \\
Wooden Products and Furniture & 2 & 1.77 \\
Construction and Public Works & 2 & 1.77 \\
Transportation, Telecommunication and Storage & 1 & 0.88 \\
Real Estate Activities & 1 & 0.88 \\
Total & 113 & 100.00 \\
\hline
\end{tabular}

Source: www.kap.gov.tr.

The IMKB and Public Disclosure Platform (PDP), the electronic disclosure system of the Turkish capital markets, database for the quarterly, semiannual and annual financial statement and price information are used. The unit of exchange for these variables is Turkish Lira (TL). In 2005, the unit of exchange was changed to New Turkish Lira (NTL), which is an equivalent of $10^{-6}$ times of Turkish Lira. Therefore, all the data for the periods before 2004 last quarter are divided by $10^{6}$ to make them comparable between the periods. Also, if there are stock splits, dividend payments or bonus issues on the announcement day of financial statements, then the prices are adjusted to remove the effects of these events. In the analysis, the exact financial statement announcement dates for each sample company are used. The Table 4 gives the descriptive statistics for sample data.

Table 4. Descriptive statistics for pooled samples

\begin{tabular}{|c|c|c|c|c|c|c|c|c|c|}
\hline & \multicolumn{3}{|c|}{$\begin{array}{c}\text { Whole Period Sample } \\
\text { (1997Q1-2011Q4) }\end{array}$} & \multicolumn{3}{|c|}{$\begin{array}{l}\text { Pooled Sample for } \\
\text { 1997Q1-2003Q3 }\end{array}$} & \multicolumn{3}{|c|}{$\begin{array}{l}\text { Pooled Sample for } \\
\text { 2003Q4-2011Q4 }\end{array}$} \\
\hline & $\mathrm{P}$ & EARN & $\mathrm{BV}$ & $\mathrm{P}$ & EARN & $\mathrm{BV}$ & $\mathrm{P}$ & EARN & BV \\
\hline Min & 0.20 & -43.96 & -4.52 & 0.39 & -9.19 & -4.52 & 0.20 & -43.96 & -2.23 \\
\hline Max & 1323.58 & 32.86 & 113.02 & 302.81 & 29.63 & 78.17 & 1323.58 & 32.86 & 113.02 \\
\hline Range & 1323.38 & 76.82 & 117.54 & 302.42 & 38.82 & 82.69 & 1323.38 & 76.82 & 115.25 \\
\hline Mean & 15.29 & 0.58 & 6.64 & 14.76 & 0.71 & 5.48 & 15.72 & 0.48 & 7.58 \\
\hline Median & 5.31 & 0.17 & 3.50 & 7.58 & 0.27 & 3.57 & 3.92 & 0.12 & 3.44 \\
\hline Standard Deviation & 49.80 & 2.02 & 10.86 & 22.94 & 2.08 & 7.07 & 63.86 & 1.96 & 13.09 \\
\hline
\end{tabular}

\subsection{Econometric Models}

In this study, three main equations are tested in measuring the explanatory power of accounting information for market values. In regression tests, Ordinary Least Squares estimation is used. Since the sample size is constant through the analysis period, balanced panel data analysis is used.

i) The first equation, named "Book Value-Earnings Relation", examines the ability of book values and earnings to explain stock prices. Consistent with Ohlson (1995), Collins et al. (1997), Francis and Schipper (1999), Brimble \& Hodgson (2007), the value relevance of financial statement information for the period of 1997-2013 is measured with the below equation:

Where

$$
P_{j, t}=\delta_{0, t}+\delta_{1, t} B V_{j, t}+\delta_{2, t} E A R N_{j, t}+\varepsilon_{j, t}
$$

$\mathrm{P}_{\mathrm{j}, \mathrm{t}}$ : The closing weighted average share price of company $\mathrm{j}$ at the announcement day of quarter $\mathrm{t}$.

$\mathrm{BV}_{\mathrm{j}, \mathrm{t}}$ : Book value of company $\mathrm{j}$ according to quarter $\mathrm{t}$ financial statements.

EARN $_{\mathrm{j}, \mathrm{t}}$ : Net earnings after tax for company $\mathrm{j}$ at quarter $\mathrm{t}$.

$\delta_{1, t}:$ Coefficient for book values 
$\delta_{2, t}$ : Coefficient for earnings

ii) Also, we test the explanatory power of earnings and book values separately. So, consistent with Collins et al. (1997), Francis \& Schipper (1999), Brimble and Hodgson (2007), the total explanatory power is divided into the following equations:

Where

$$
\begin{aligned}
& P_{j, t}=\rho_{0, t}+\rho_{1, t} B V_{j, t}+\varepsilon_{j, t} \\
& P_{j, t}=\alpha_{0, t}+\alpha_{1, t} E A R N_{j, t}+\varepsilon_{j, t}
\end{aligned}
$$

$\rho_{1, t}:$ Coefficient for book values

$\alpha_{2, t}$ : Coefficient for earnings

All the variables in three equations are being normalized dividing by the average number of outstanding shares during the related quarter.

iii) Also, we measure the effects of adoption of new financial reporting standards. In that respect, the data is divided into two periods: One is 1997 first quarter (Q1)-2003 third quarter (Q3) (before new regulations) and the other one is 2003 annual (Q4)-2011Q4 (after new regulations). Different from Turel (2009), Suadiye (2012) and Kargin (2013), we divide our time period from 2003Q4 since the first new reporting regulations on inflation adjustments and consolidation of accounts were put into force starting from that period's financial statements. The above mentioned three equations are also tested for each sub-period and the value relevance of accounting information before and after new regulations are compared.

\section{Results}

Table 5, 6 and 7 demonstrate the regression results for each equation. Results are given in the order of whole sampling period of 1997Q1-2011Q4, before new reporting standards period (1997Q1-2003Q3) and after new reporting standards period (2003Q4-2011Q4).

According to Lilliefors test results, the residuals are normally distributed. For the quarterly periods, at 5\% significance level Durbin Watson test statistics are between acceptable ranges, indicating that there is no residuals' autocorrelation. In our Ohlson Model (1995) findings (both quarterly and whole period results), Variance Inflation Factors (VIFs) values are lower than 10, which means that no multicollinearity between book values and earnings exists.

For all regression results, both in the pooled quarterly and all periods analysis, the regression coefficients are statistically significant at $1 \%$ significance level. Also, the $\mathrm{F}$ statistics that determine the validity of model as a whole are statistically significant at $1 \%$ level in each quarter and also in all periods' analysis. So, the earnings and book values are value relevant in explaining prices in IMKB stock markets. Also, each variable individually is value relevant.

Table 5 shows the regression results for our first equation which is book values, earnings and prices relation. The whole period results reveal that the explanatory power of earnings and book values is $40.46 \%$. As a robustness check, when we look at the quarterly results, we see consistent results with whole period analysis. The adj- $\mathrm{R}^{2}$ for the first quarter (Q1) is 38.37\%, for the second quarter (Q2) 40.93\%, for the third quarter (Q3) $41.37 \%$ and for the annual financial statements (Q4) $43.75 \%$.

Table 6 demonstrates the regression results for book values and prices relation. According to whole period results, book values explain $37.49 \%$ of announcement date prices. The quarterly results reveal that the adj- $\mathrm{R}^{2}$ for Q1 is $35.04 \%$, for Q2 it is $39.53 \%$, for Q3 it is $38.46 \%$ and for Q4 it is $38.71 \%$.

Table 7 includes the separate value relevance of earnings. Mainly the value relevance of book values is higher than the value relevance of earnings. Our whole period results reveal the value relevance of earnings is $21.12 \%$ and quarterly results demonstrate that the adj- $\mathrm{R}^{2}$ for Q1 is $16.14 \%$, for Q2 it is $15.96 \%$, for Q3 it is $30.15 \%$ and for Q4 it is $28.33 \%$. 
Table 5. Pooled cross-sectional regressions of prices on earnings and book values ${ }^{\text {a }}$

\begin{tabular}{|c|c|c|c|c|c|c|c|c|c|c|c|c|c|c|c|}
\hline \multirow[b]{3}{*}{ Periods } & \multicolumn{15}{|c|}{$P_{j, t}$} \\
\hline & \multicolumn{5}{|c|}{ 1997Q1-2011Q4 Results } & \multicolumn{5}{|c|}{ 1997Q1-2003Q3 Results } & \multicolumn{5}{|c|}{ 2003Q4-2011Q4 Results } \\
\hline & $\delta_{l, t}$ & & $\delta_{2, t}$ & & Adj-R ${ }^{2}$ & $\delta_{1, t}$ & & $\delta_{2, t}$ & & Adj-R ${ }^{2}$ & $\delta_{l, t}$ & & $\delta_{2, t}$ & & Adj-R ${ }^{2}$ \\
\hline Q1 & 2.4525 & $*^{\mathrm{d}}$ & 12.7134 & * & 0.3837 & 1.6503 & * & 7.6352 & * & 0.2992 & 2.5985 & * & 16.7239 & * & 0.4152 \\
\hline Q2 & 2.143 & * & 2.9768 & * & 0.4093 & 1.1509 & $*$ & 5.5522 & * & 0.5158 & 2.3872 & * & 2.273 & * & 0.4113 \\
\hline Q3 & 2.0891 & * & 6.3647 & * & 0.4137 & 0.8153 & $*$ & 5.619 & * & 0.5079 & 2.1967 & * & 9.3949 & * & 0.4384 \\
\hline Q4 & 2.3892 & $*$ & 5.4037 & $*$ & 0.4375 & 0.93 & $*$ & 4.2361 & * & 0.4371 & 2.1908 & $*$ & 8.8639 & $*$ & 0.4657 \\
\hline $\begin{array}{c}\text { All } \\
\text { Periods }\end{array}$ & 2.3422 & * & 4.9443 & $*$ & 0.4046 & 1.2418 & * & 4.0767 & $*$ & 0.3952 & 2.5193 & $*$ & 6.3168 & $*$ & 0.4263 \\
\hline
\end{tabular}

Table 6. Pooled cross-sectional regressions of prices on book values ${ }^{b}$

\begin{tabular}{|c|c|c|c|c|c|c|c|c|c|}
\hline \multirow[b]{3}{*}{ Periods } & \multicolumn{9}{|c|}{$\mathrm{P}_{\mathrm{j}, \mathrm{t}}$} \\
\hline & \multicolumn{3}{|c|}{ 1997Q1-2011Q4 Results } & \multicolumn{3}{|c|}{ 1997Q1-2003Q3 Results } & \multicolumn{3}{|c|}{ 2003Q4-2011Q4 Results } \\
\hline & $\rho_{l, t}$ & & Adj-R ${ }^{2}$ & $\rho_{l, t}$ & & Adj-R ${ }^{2}$ & $\rho_{l, t}$ & & Adj-R ${ }^{2}$ \\
\hline Q1 & 2.829 & $*$ & 0.3504 & 1.9198 & $*$ & 0.2531 & 3.0802 & $*$ & 0.3792 \\
\hline Q2 & 2.3829 & $*$ & 0.3953 & 1.7875 & $*$ & 0.3983 & 2.5544 & $*$ & 0.4051 \\
\hline Q3 & 2.8195 & $*$ & 0.3846 & 1.6657 & $*$ & 0.3707 & 3.1801 & $*$ & 0.4071 \\
\hline Q4 & 3.1487 & $*$ & 0.3871 & 1.5875 & $*$ & 0.185 & 3.4762 & $*$ & 0.4278 \\
\hline All Periods & 2.8088 & $*$ & 0.3749 & 1.7206 & $*$ & 0.281 & 3.0956 & $*$ & 0.4027 \\
\hline
\end{tabular}

Table 7. Pooled cross-sectional regressions of prices on earnings ${ }^{c}$

\begin{tabular}{|c|c|c|c|c|c|c|c|c|c|}
\hline \multirow[b]{3}{*}{ Periods } & \multicolumn{9}{|c|}{$P_{j, t}$} \\
\hline & \multicolumn{3}{|c|}{ 1997Q1-2011Q4 Results } & \multicolumn{3}{|c|}{ 1997Q1-2003Q3 Results } & \multicolumn{3}{|c|}{ 2003Q4-2011Q4 Results } \\
\hline & $\alpha_{1, t}$ & & Adj-R ${ }^{2}$ & $\alpha_{l, t}$ & & Adj-R $^{2}$ & $\alpha_{1, t}$ & & Adj-R $^{2}$ \\
\hline Q1 & 25.6471 & * & 0.1614 & 12.138 & * & 0.1303 & 34.9895 & * & 0.2 \\
\hline Q2 & 8.7999 & * & 0.1596 & 8.5676 & $*$ & 0.4005 & 8.9086 & $*$ & 0.1297 \\
\hline Q3 & 14.8827 & * & 0.3015 & 7.8433 & $*$ & 0.4562 & 20.9253 & $*$ & 0.3513 \\
\hline Q4 & 10.6354 & * & 0.2833 & 4.9089 & $*$ & 0.3811 & 17.9878 & $*$ & 0.3988 \\
\hline All Periods & 11.3485 & $*$ & 0.2112 & 5.7681 & * & 0.2723 & 16.5634 & $*$ & 0.2585 \\
\hline
\end{tabular}

Notes: ${ }^{\mathrm{a}} P_{j, t}=\delta_{0, t}+\delta_{1, t} B V_{j, t}+\delta_{2, t} E A R N_{j, t}+\varepsilon_{j, t} \cdot{ }^{\mathrm{b}} P_{j, t}=\rho_{0, t}+\rho_{1, t} B V_{j, t}+\varepsilon_{j, t}{ }^{\mathrm{c}} P_{j, t}=\alpha_{0, t}+\alpha_{1, t} E A R N_{j, t}+\varepsilon_{j, t}$.

${ }^{\mathrm{d}}$ Statistically significant at $1 \%$.

Table 8. Number of observations is given in the following table

\begin{tabular}{|c|c|c|c|c|c|c|c|c|c|}
\hline $\begin{array}{l}\text { Number of } \\
\text { observations }\end{array}$ & \multicolumn{3}{|c|}{ 1997Q1-2011Q4 } & \multicolumn{3}{|c|}{ 1997Q1-2003Q3 } & \multicolumn{3}{|c|}{ 2003Q4-2011Q4 } \\
\hline & Q1, Q2, Q3 & Q4 & All Periods & Q1, Q2, Q3 & Q4 & All Periods & Q1, Q2, Q3 & Q4 & All Periods \\
\hline Observations & 113 & 113 & 113 & 113 & 113 & 113 & 113 & 113 & 113 \\
\hline Cross-sections & 15 & 15 & 60 & 7 & 6 & 27 & 8 & 9 & 33 \\
\hline $\begin{array}{l}\text { Total pooled } \\
\text { (balanced) } \\
\text { observations }\end{array}$ & 1695 & 1695 & 6780 & 791 & 678 & 3051 & 904 & 1.017 & 3729 \\
\hline
\end{tabular}

Figures 5, 6 and 7 demonstrate the value relevance before and after new regulations comparatively. For first equation, the whole period analysis demonstrates that there is an increase in the value relevance of combined book values and earnings from $39.52 \%$ to $42.63 \%$ after new reporting standards. When we look at the quarterly results, Q1 and Q4 results demonstrate an increase in value relevance, too. For Q1 financial statements, the value relevance increases from $29.92 \%$ to $41.52 \%$ and for Q4, from $43.71 \%$ to $46.57 \%$. On the other hand, in Q2 and Q3 there is a fall in adj- $\mathrm{R}^{2} \mathrm{~s}$ after new reporting standards. In Q2 it decreases from $51.58 \%$ to $41.13 \%$ and in Q3 from $50.79 \%$ to $43.84 \%$. Other graphs reveal that these decreases are mainly caused by the decreased value relevance of earnings. For second equation, the trustworthiness of book values increase both in quarterly and whole period results. Especially, in Q1, Q3 and Q4, there are sharp rises in the value relevance of book values after new reporting standards are introduced. Also, whole period results show that the explanatory power of book values rise $28.10 \%$ to $40.27 \%$ after adoption of new reporting standards. According to third equation results, although there are increases in the value relevance of earnings in Q1 and Q4, there are sharp decreases in the value relevance of earnings in Q2 and Q3 after the adoption of new reporting standards. In Q2 adj- $\mathrm{R}^{2}$ falls from $40.05 \%$ to $12.97 \%$ 
and in Q3 from $45.62 \%$ to $35.13 \%$. As a result of these sharp decreases, the whole period analysis for earnings and prices relation also reveals a slight decrease in value relevance from $27.23 \%$ to $25.85 \%$.

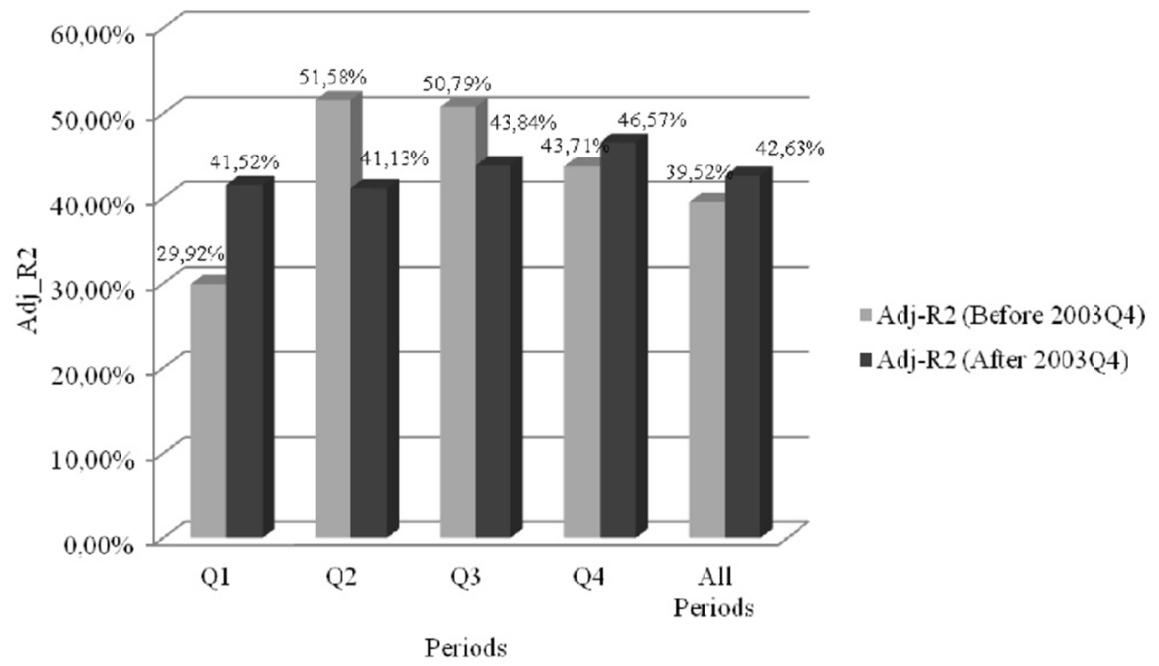

Figure 5. Comparison of adj- $\mathrm{R}^{2} \mathrm{~s}$ before and after new financial reporting standards for prices, book values and earnings relation

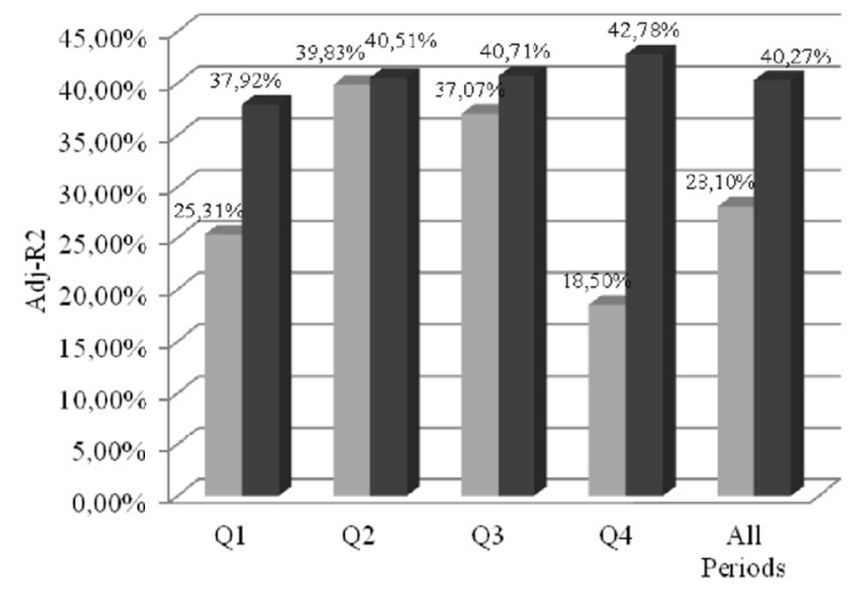

$\because$ Adj-R2 (Before 2003Q4)

-Adj-R2 (After 2003Q4)

Periods

Figure 6. Comparison of adj- $\mathrm{R}^{2} \mathrm{~s}$ before and after new financial reporting standards for prices and book values relation 


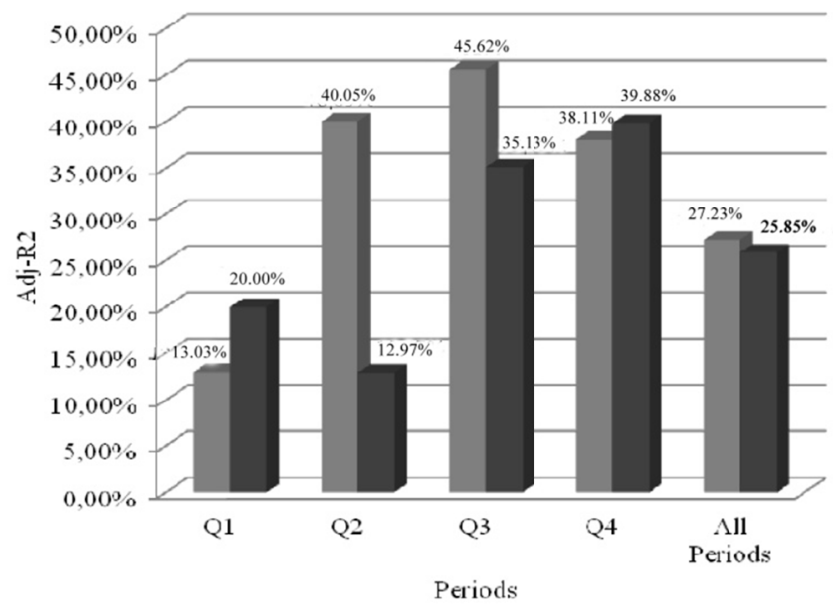

- Adj-R2 (Before 2003Q4)

- Adj-R2 (Allel 2003Q4)

Figure 7. Comparison of adj- $\mathrm{R}^{2} \mathrm{~s}$ before and after new financial reporting standards for prices and earnings relation

\section{Summary and Conclusions}

This paper extends the research on the value relevance of accounting information in the Turkish stock markets. It is the first value relevance study that covers a period of 15 years and measures the value relevance with quarterly data in Turkish stock markets. Different from other Turkish value relevance studies, the exact financial statement announcement date prices are used. So, it moves the findings about the value relevance of financial information and the effects of new financial reporting standards on the value relevance of accounting information in the Turkish stock markets one step further.

Under the Ohlson Model (1995), combined book values and earnings are significantly value relevant in explaining the prices in the Turkish stock markets. The book values and earnings are also individually significantly value relevant. Book values' explanatory power is higher than earnings' explanatory power.

The consolidation and inflation adjustments standards that have been applied starting from 2003 annual financial statements, revised translations of IFRS in 2005 and TFRS that are one by one translation of IFRS in 2008 improved combined value relevance of book values and earnings in the Turkish stock markets. However, separate analysis results reveal that although there is a large increase in the value relevance of book values, there is a decrease in the value relevance of earnings after adoption of new reporting standards. So, the increase in the combined value relevance is mainly due to the increase in book values' value relevance.

\section{References}

Armstrong, C. S., Barth, M. E., \& Riedl, E. J. (2010). Market reaction to the adoption of IFRS in Europe. The Accounting Review, 85(1), 31-61. http://dx.doi.org/10.2308/accr.2010.85.1.31

Ball, R., \& Brown, P. (1968). An empirical evaluation of accounting income numbers. Journal of Accounting Research, 160-177.

Bamber, L. S. (1968). The information content of annual earnings releases: A trading volume approach. Journal of Accounting Research, 24(1), 40-56. http://dx.doi.org/10.2307/2490803

Barth, M. E., Beaver, W. H., \& Landsman, W. R. (2001). The relevance of the value relevance literature for financial accounting standard setting: Another view. Retrieved from http://papers.ssrn.com/sol3/papers.cfm?abstract_id=246861.26/03/2013

Brimble, M., \& Hodgson, A. (2007). On the intertemporal value relevance of conventional financial accounting in Australia. Accounting and Finance, 47, 599-622. http://dx.doi.org/10.1111/j.1467-629X.2007.00241.x

Celasun, O. (1998). Macroeconomics and growth group development research department, the world bank, the 1994 currency crisis in Turkey. Retrieved from http://www-wds.worldbank.org/external/default/WDSContentServer/IW3P/IB/1998/04/01/000009265_398 0624143318/Rendered/PDF/multi_page.pdf

Clarkson, P., Hanna, J. D., Richardson, G. D., \& Thompson, R. (2009). The impact of IFRS adoption on the value relevance of book value and earnings. Retrieved from http://ssrn.com/abstract=1614362 
Collins, D. W., Maydew, E. L., \& Weiss, I. S. (1997). Changes in the value relevance of earnings and book values over the past forty years. Journal of Accounting and Economics, 39-67. http://dx.doi.org/10.1016/S0165-4101(97)00015-3

Collins, D. W., Pincus, M., \& Xie, H. (1999). Equity valuation and negative earnings: The role of book value of equity. The Accounting Review, 74(1), 29-61. http://dx.doi.org/10.2308/accr.1999.74.1.29

Devalle, A., Onali, E., \& Magarini, R. (2010). Assessing the value relevance of accounting data after the introduction of IFRS in Europe. Journal of International Financial Management and Accounting, 21(2), $85-119$.

Dincer, B. (2009). The impact of adoption of IAS/IFRS on information asymmetry in Istanbul stock exchange. YÖK.

Easton, P. D. (1999). Security returns and the value relevance of accounting data. Accounting Horizons, 13(4), 399-412. http://dx.doi.org/10.2308/acch.19 99.13.4.399

Francis, J., \& Schipper, K. (1999). Have financial statements lost their relevance? Journal of Accounting Research, 37(2), 319-352. http://dx.doi.org/10.2307/2491412

GAAP. (2001). A survey of national accounting rules benchmarked against international accounting standards. Retrieved from http://www.gthonduras.com/pdf/GAAP\%202001.pdf

Holthausen, R. W., \& Watts, R. L. (2001). The relevance of the value-relevance literature for financial accounting standard setting. Journal of Accounting and Economics, 3-75. http://dx.doi.org/10.1016/S0165-4101(01)00029-5

Jermakowixz, E. K., Kinsey, J., \& Wulf, I. (2007). The value relevance of accounting income reported by DAX-30 german companies. Journal of International Financial Management and Accounting, 18(3), 151191. http://dx.doi.org/10.1111/j.1467-646X.2007.01011.x

Kargin, S. (2013). The impact of IFRS on the value relevance of accounting information: Evidence from Turkish firms. International Journal of Economics and Finance, 5(4), 71-80. http://dx.doi.org/10.5539/ijef.v5n4p71

Kothari, S. P. (2001). Capital markets research in accounting. Journal of Accounting \& Economics, 31, 105-231. http://dx.doi.org/10.1016/S0165-4101(01)00030-1

Landsman, W. R., \& Maydew, E. L. (2002). Beaver (1968) revisited: Has the information content of quarterly earnings announcements declined in the past three decades? Journal of Accounting Research, 40(3), 797808. http://dx.doi.org/10.1111/1475-679X.00071

Lev, B. (1989). On the usefulness of earnings and earnings research: Lessons and directions from two decades of empirical research. Journal of Accounting Research, 27, 153-192. http://dx.doi.org/10.2307/2491070

Nichols, D. C., \& Wahlen, J. M. (2004). How do earnings numbers relate to stock returns? A review of classic accounting research with updated evidence. Accounting Horizons, 18(4), 263-286. http://dx.doi.org/10.2308/acch.2004.18.4.263

Ohlson, J. A. (1995). Earnings, book values and dividends in equity valuation. Contemporary Accounting Research, 11(2), 661-687. http://dx.doi.org/10.1111/j.1911-3846.1995.tb00461.x

Ozatay, F. (1994). The 1994 currency crisis in Turkey. Retrieved from http://www.econturk.org/Turkisheconomy/ozat2.pdf

Ozatay, F., \& Sak, G. (2002). The 2000-2001 financial crisis in Turkey. Retrieved from http://home.ku.edu.tr/ cakcay/ozataysak.pdf

Suadiye, G. (2013). The value relevane of book value and earnings under the local GAAP and IFRS: Evidence from Turkey. Ege Academic Review, 12(3), 301-310.

Temiz, D., \& Gokmen, A. (2009). The 2000-2001 financial crisis in Turkey and the global economic crises of 2008-2009: Reasons and comparisons. Retrieved http://www.sobiad.org/eJOURNALS/journal_IJSS/arhieves/IJSS-2009/01dilek-temiz.pdf

Turel, A. (2009). The value relevance of IFRS: The case of Turkey. Economica, 119-128.

Uygur, E. (2010). Global crisis and Turkish economy. Retrieved from http://www.finance.thirdworldnetwork.net/file_dir/6158100194dca5b2b6bb0f.pdf 


\section{Note}

Note 1. Capital Markets Board Law no. 6362 put into force after being published in the Official Gazette dated December 30, 2012. Pursuant to article 138 of the Law, Borsa İstanbul A.Ş. convened all the exchanges operating in the Turkish capital markets under a single roof. On April 5, 2013, upon being registered and announced, Borsa Istanbul A.S. received a foundation and operation permit. Yet, in this study, Borsa Istanbul will be referred to as Istanbul Stock Exchange (IMKB), since Borsa Istanbul A.S. was non-existent during the 19972011 period.

\section{Copyrights}

Copyright for this article is retained by the author(s), with first publication rights granted to the journal.

This is an open-access article distributed under the terms and conditions of the Creative Commons Attribution license (http://creativecommons.org/licenses/by/3.0/). 